\title{
Nationalism and Declining Population in Bulgaria after 1990
}

\author{
Tatyana Kotzeva, Elitsa Dimitrova
}

\begin{abstract}
This paper aims to illuminate and provide a critical assessment of the nationalist discourse on declining population in Bulgaria. Nationalist discourse is one of the mainstream approaches in Bulgaria and is widely spread through mass media having been voiced by renowned intellectuals, policy experts, scholars and media celebrities. It can be recognised in the political programmes of left-wing and nationalist parties, but also in governmental documents at both national as well as regional levels. The nationalistically oriented advocates articulate current concerns regarding the declining birth rates and declining population in the country labelling the demographic situation as "Bulgarian national catastrophe" and "Bulgaria's collapse". They place an emphasis on the decreasing proportion of ethnic Bulgarians and the growth of the ethnic minorities, especially Roma. The latter trend was labelled by the derogatory term "gypsyisation", i.e. a distortion of the Bulgarian nation and shrinkage of its core ethnicity - ethnic Bulgarians. The threat of the "gypsyisation" of the Bulgarian nation has not only been viewed in quantitative terms, but also through the lens of an alleged worsening of the national human capital (e.g. level of education, professional skills and civic culture of the population). Another set of arguments exploited in the nationalist discourse is the diminishing size of the Bulgarian nation as a threat to national sovereignty, territorial unity and economic stability.

We use a qualitative content analysis and thematic analysis of media textual materials in order to reconstruct the main ideas, arguments and strategies of the proponents of the nationalist discourse regarding the consequences of the declining population in Bulgaria, its social policy implications and future demographic prospects.
\end{abstract}

Keywords: Nationalism • Population decline · Ethnic minorities · Roma - Bulgaria • Qualitative content analysis · Thematic analysis 


\section{Introduction}

\subsection{Population decline and ethno-stratification in Bulgaria after 1990}

The transition period in Bulgaria was characterised by profound transformations in all aspects of social life. Severe economic downturn, skyrocketing inflation, and high unemployment rates in the mid-1990s followed by mass impoverishment and significant deterioration of living standards were the main features of the crisis-led societal transformations. These transformations also had a significant impact on the demographic development of the country. After 1990, the rate of natural increase became negative. This trend persisted throughout the whole period of the last two decades. In 2012, the rate of natural increase reached $-5.5 \%$ (Demographic processes 2013).

As stated by D. Coleman and R. Rowthorn (2011: 219): "Population decline can arise from any combination of low birth rates, high death rates, and net emigration. In the modern world, low birth rates are the key". This combination of factors shaped Bulgaria's demographic development from the beginning of the 1990s onwards. The persistent population decline witnessed in the country after 1990 has been caused by the intensified process of emigration, increasing levels of mortality and changes in reproductive models associated with postponement of the onset of reproduction and reduction in the number of children the contemporary young people choose to have. In particular, it has been estimated that for the period 19902005 the population loss due to out-migration exceeds one million (out of 7369431 according to the last census of 01/02/2011). The trend of emigration has been extremely intensive in the initial years of the transition period.

The population decline in the country has also been caused by the increasing trends of mortality. The situation is particularly dramatic because mortality has retained at a very high level of above 14\%o, reaching $15.0 \%$ in 2012 (the highest crude death rate in Europe) with no signs of improvement in the coming years (Demographic processes 2013). The increase of mortality rates was triggered by several underlying processes - deterioration of the health status of the population due to a significant drop of living standards and population ageing associated with a process of fertility reduction and changes in the cohort size that had been in effect long before the societal transition.

Important differentials in mortality following the increasing social inequalities in the country have been discussed in the literature as well. Ethno-stratification of the Bulgarian post-socialist society and the increasing inequalities between the three main ethnic groups in the country (Bulgarian, Turkish and Roma) is also reflected by diverging mortality trends. The national statistics recorded excessively higher infant mortality and also significantly lower life expectancy at birth among the ethnic Roma. These inequalities continued to reproduce and increased even further over the last two decades (Table 1).

Substantial ethnic differentials are observed in fertility trends as well. The Roma minority has the highest level of fertility (Table 1). Koytcheva and Philipov (2008: 373) point out also that "Roma often enter into motherhood as teenagers, while for 
Tab. 1: Main demographic characteristics of Bulgarian, Turkish and Roma ethnic groups in Bulgaria

\begin{tabular}{lrrr}
\hline & Bulgarians & Turks & Roma \\
\hline Share in the total population (2011) in \% $^{1}$ & 84.8 & 8.8 & 4.9 \\
Total fertility rate (2001) $^{2}$ & 1.1 & 2.3 & 3.0 \\
Average number of children - women age at 45-49 (2011) $^{1}$ & 1.6 & 2.0 & 2.8 \\
Average number of children - women age at 65-69(2011) $^{1}$ & 1.8 & 2.6 & 3.2 \\
Mean age at first birth (2000) $^{2}$ & 24.2 & 21.1 & 20.1 \\
Infant mortality rate (2003) in \% $^{3}$ & 9.9 & 17.0 & 28.0 \\
Life expectancy at birth (1999-2001) $^{3}$ & 71.8 & - & 61.8 \\
\hline
\end{tabular}

Source: ${ }^{1}$ Population Census Report 2011; ${ }^{2}$ Koytcheva/Philipov 2008: $373-374 ;{ }^{3}$ National Health Strategy for People Belonging to Ethnic Minorities 2005-2012.

the Turks the mean age at entry is between 20 and 21, and Bulgarians start childbearing above age 23 on average. Also, in the second half of the 1990s we observe a rise in the mean age at first birth that is especially evident for the Bulgarians and the Roma".

The sharp decrease of the Total Fertility Rate (TFR) recorded since the early 1990s marked the end of the two-child family model as previously dominant compositional characteristic of the Bulgarian family. Since 1990, the TFR dropped from a stable level of approximately two children per woman that prevailed during the socialist times leading to the "lowest low fertility level" less then 1.3 children per woman (Kohler et al. 2002: 641-680) in the mid-1990s. In 2012, after a period of slight increase, the national TFR reached the level of 1.50 children per woman (Demographic Processes 2013).

The changes in the number of children born in today's Bulgarian families involved mainly higher-order fertility, and in particular, second births. Among the young generations today, the second birth is increasingly postponed and even foregone. Several studies show that the arrival of the second child in the family could be seen as an intersection of enlarging social inequalities in modern Bulgarian society (Koytcheva/Philipov 2008; Dimitrova 2012). In particular, the advancing ethno-stratification of the Bulgarian post-socialist society turned reproduction into a socially stratified phenomenon that follows the increasing social inequalities between different ethnic groups. Until recently Roma women who experienced the most severe socio-economic deprivation continued to have significantly increased probability of second and higher order births compared to the women from the other two ethnic groups in the country, although the analysis reveals that in the Roma ethnic group, the decline in higher-order fertility has also been occurring after 1990 (Dimitrova 2011).

All these changes in the demographic profile of the country and the persistent ethnic differentials in fertility, witnessed in particular after 1990, focused the attention of experts, policy makers, and civil society. The issue of population decline and exceptionally plummeting fertility became a subject converging the discourses 
of various stakeholders on searching means to counteract further negative demographic implications. On the other hand, higher birth rates and the worsening living conditions for raising children in the families of the Roma minority raise public concerns. Reproductive models in other minorities, especially the Turks, do not attract politicians' attention as they go in line with overall demographic trends.

\subsection{Methodology}

In this paper, our main research question is "How is Bulgaria's population decline after 1990 framed in the context of nationalist discourse?" Thus, our focus is on the content of public speech on "demographic crisis", on comprehensions of demographical trends and their social effects rather than on the objective measurements of demographic data. "Discourses are practices that generate the things (e.g. the "population") [...] [they] exert describable effects [....] they are no nature-given units but owe their existence to specific historical constellations [....]" (Etzemuller 2011: 102). Our aim is to extract the main traits of the nationalist rhetoric on the "population problem" that is embedded into a conception of "demography as construction" (Etzemuller 2011: 101). In this vein, it is interesting to understand how the "demographic crisis" is articulated in the frame of nationalism.

The demographic structure of the nation represents a key element in nationalist mode of thinking. Thus, it is not surprising that the nationalist visions and interpretations of the "population problem" prevail in a context of the upheaval of "nationalising nationalisms" of the political space of today's post-communist European countries, in which the dismantling of the socialist state unlocked ethnic tensions previously suppressed by the totalitarian regimes (Brubaker 2004).

After a brief macro-level analysis of the expected outcomes of the persisting population decrease in a long-term perspective, which has been labelled a "demographic crisis" in the public discourse, the paper outlines the main conceptualisations of nationalism and the ideas of a nation's reproduction and ethnic homogeneity in the framework of "politics of reproduction". The conceptualisation of population shrinkage and population ageing as a societal and national "threat" is presented in a "apocalyptic demography" that has been used to "reconstruct and redefine social problems in ways that fit a political agenda or, at least, that calibrate with current and popular ideological positions" (Gee 2002: 750; see also Gee/Gutman 2000; Vincent 1996). In the post-socialist Bulgarian context, it is the nationalist ideology that addresses all social and economic problems by reference to the "demographic crisis". And vice versa, current talk about demography is void if nationalist thinking is not present in it.

In the empirical section of the paper, we try to extract different themes and nuances of interpretations/representations of the term "demographic crisis" within the framework of nationalist thought. Particularly, we will try to reconstruct the manners in which the topics related to the country's population shrinkage are framed in official positions of experts/researchers and politicians as well as in the vox populi represented in online forums and blogs. 
Data collected for this analysis include thematic discussions in electronic media, internet forums, and blogs as well as the official speeches and media publications by leaders of the $\mathrm{VMRO}^{1}$ - a party that falls in the extreme right of the political spectrum. The party describes itself as a nationalist and patriotic organisation, whose mission is the country's demographic development and the defence of the Bulgarian values including the protection of the traditional Bulgarian family. The reason for choosing the VMRO as a representative nationalist party of the Bulgarian political landscape is that the party has developed a very detailed programme/strategy on the country's demographic future and it is very active in public debates with demographic reference covered on e-media, TV and printing press. Although the VMRO has not been in Parliament for the last decade, an analysis of the party's statements might be useful as it is assumed that they contain the archetypical structure of nationalist discourse in Bulgaria. In the last 3 years, the VMRO leaders present themselves not only as politicians but as researchers when presenting a demographic expertise in the public.

The method that we use to analyse the collected material is a qualitative content analysis of textual materials (Mayring 2000; Keller 2005). We have set Google Alerts to receive all articles on the "population topic" and, for the aim of this research, we only chose articles in Bulgarian, published online between 1st October 2011 and 1st June 2012. Additionally, we gathered further online publications from this period, which were not found by the Google Alerts. In order to find these online publications, we entered the following search terms in Google: "demographic crisis", "demographic policy" and "fertility in Bulgaria". Our material comprises newspapers (e.g. interviews, author's articles), videos (e.g. textual materials from television programs), forums and blogs as well as informational websites. Our final sample consisted of 317 articles.

The collected material was downloaded and the contents were thematically analysed by Atlas.ti (v.7.0). The coding scheme tracked such categories as: general information about each article (informative, argumentative, discussion), tone of the article (optimistic/positive, neutral/balanced, pessimistic/negative), concerns and fears (explicit, implicit), accuracy of information conveyed, sources cited, (possible) solutions/recommendations. Our coding identified and summarised the content of the materials under three main sub-categories/modes of thinking: nationalist, (neo) liberal and state-interventionist. ${ }^{2}$ For example, the material was coded as nationalist if expressions like "ethnicity", "minority", "ethnic ratio", "ethnic rights" are used to express the superiority of a certain national ethnic group. According to our three "deductive categories" (Mayring 2000), we identified 66 individual articles as "nationalist" (of which 21 were published on the VMRO website) and discursively analysed their content.

1 VMRO-Bulgarian National Movement is one of the oldest political parties in Bulgaria founded more than 100 years ago as a national organisation of liberation of Bulgarians in Macedonia.

A comparative analysis of nationalist, (neo)liberal and state-interventionist framing patterns is not the purpose of this paper and must be conducted in another article. 


\section{The focus on "demographic crisis" rhetoric instead of "national population decline"}

The importance and the anticipated negative consequences of the long-lasting trend of depopulation for all spheres of the Bulgarian society have been widely discussed for more than two decades. The public discourse on the country's demographic situation is characterised by an extreme terminology. It is described as a "national catastrophe", "collapse of the nation" or "heavy crisis" rather than more neutrally as "population decline" or "depopulation".

Although the decrease in fertility and the increase in mortality, which presumably caused the recent demographic developments have already taken place in the 1970 s and 1980s, the strongest effects became visible at the beginning of the $21^{\text {st }}$ century.

The population decrease beginning in the early 1990s continued in the first decade of the $21^{\text {st }}$ century despite a minor increase in fertility in the period 2004-2009 (celebrated by the national media as a "baby boom") and a decreasing emigration during the same period. Public concerns about the severity of the population decline are additionally reinforced by two statistics. First, even the optimistic variant of the demographic forecasts prepared by the National Statistical Institute in Bulgaria predict that the negative population growth will continue uninterruptedly until 2060 . Second, of all EU countries, Bulgaria showed the lowest negative natural growth for the last decade and in the World Bank population analyses the country has been ranked as the EU country with the highest pace of population loss. Coleman and Rowthorn (2011: 220, 238) point out that "[...] a rate of decline of 0.5 percent per year seems quite rapid in the context of historical and current experience". Bulgaria is the only EU country experiencing an annual total population decline of $-4.41 \%$.

The public discourse on the "demographic crisis" is associated mainly with a steep fertility decline, which is interpreted as a response to severe economic hardships and low living standards during the last two decades. Moreover, in a broader context, the label of "demographic crisis" has been used as a landmark connoting transformations with negative consequences in all areas of social life. The fear of a "demographic crisis" penetrates public debates on most important issues. It is closely related to unemployment, generally low salaries and pensions, expensive dwelling, scarcity of childcare services in big cities, etc. For a number of reasons, the "population problem" has been considered as particularly severe:

- First of all, the demographic crisis is characterised by its comprehensiveness. It has an impact on all spheres and institutions of the Bulgarian society. It affects the labour market, the educational sphere, the healthcare system, the national pension system, and the social care system. For example, it has led to several important changes in the area of education. From 1990 onwards, many kindergartens and schools in small towns and villages closed down because of the low number of enrolled children; many schools faced a decrease of the in-class size, which led to amalgamating schools and classes and a decreasing quality of education. In the last 3-4 years, the consequenc- 
es of persistently low fertility are actively discussed by authorities of the higher education system. Again, the significantly low number of registered students applying and enrolling in Bulgarian universities has been seen as an outcome of the "demographic crisis". The shortage of labour force in certain segments of the labour market, the significant drop of working age population paralleled by a substantial increase of the number of people at retirement age have been expected to lead to long-lasting deficits in the national pension funds and the national insurance system in the future. Finally, the gloomy statistics assume that in the country's demographic "future", in addition to the 200 settlements, which have been deserted over the last 20 years another 1000 rural settlements will be depopulated in the next 10 years. To summarise, every problem that has evolved in any social sphere of the Bulgarian society has been considered as an outcome of the "demographic crisis".

- Much attention has been paid to population ageing as one of the most negative aspects of the country's "demographic crisis". Mass media comprehensively cite official sources of information that Bulgaria is among the world's top 5 countries with the highest percentage of people above the age of 65 . The advanced process of population ageing constitutes a solid argument for public officials to justify the lack of progress in never-ending chaotic reforms in the health and pension system during the last 10 years. On the other hand, social experts alarm for other challenges stemming from ageing. The increase in the share of senior citizens raises the issue of providing them with economic stability and wellbeing. Evidently, the diminishing number of young cohorts entering the labour markets will face this challenge - a problem that can seriously erode social solidarity as a fundamental principle of modern society. Last but not least, the increasing importance of senior citizens' votes in the national elections lead to increasing public attention to their needs and the development of future policies designed for elderly people (Krastev 2011).

- Another key dimension of academic research and public discourse is the potential decrease in the human capital of the next generations. Some scholars claim that the demographic crisis proceeds at different paces and affects the various social strata, regions and communities in the country in different ways (Mirchev 2010). This raises serious concerns about the quality of the human capital of the next generations as the current trends reflect the hampered reproduction of "genuine" Bulgarian citizens. In the same vein, differences at mortality have also been closely associated with increasing health inequalities among different social groups in Bulgaria.

However, the declining population is not a unique process exclusive to the Bulgarian society. This process has also been witnessed in most European countries and presents fundamental challenges to them. In 2008, 14 countries in Europe face 
population shrinkage including 12 East European countries together with Italy and Germany (Coleman/Rowthorn 2011: 220). Despite the fact that in the official documents of the European Commission the terms "demographic crisis" and "demographic policy" are not used, these documents frequently discuss the need of fostering population growth, to support Europe's young people to have the number of children they desire, and to guarantee solidarity between generations (EC 2011). Unlike West European countries, and similarly to some ex-socialist countries, e.g. Russia (/sola 2008), in Bulgaria terms like "demographic crisis" and "demographic catastrophe" have become a central part of the debate on population decline. The "crisis" rhetoric echoes the country's socialist past with its coercive pronatalist demographic policy. Thus, in a situation when the "future of the nation" has been considered at stake due to population decline, the "crisis" rhetoric becomes relevant for persuasive and argumentative purposes in the discourses of public agents with nationalist attitudes.

\section{$3 \quad$ Nationalism and nation reproduction}

Before discussing the manner in which the "demographic crisis" is discursively constructed in some of the official public discourses in the recent Bulgarian society we will briefly touch upon the main conceptualizations of nationalism. Not aiming to delve in a comprehensive debate on nationalism, national state, ethnicity, etc. i.e. topics that lay beyond the scope of this paper, we rather briefly elaborate on some main theses that we use as analytical instruments in our empirical analysis.

Modern theorists of nationalism unanimously agree that nationalism is not a monolithic phenomenon. Further, it is not a universal but a "contextual" concept that encompasses different meanings and modes of development according to a diverse range of socio-cultural environments. Nationalism is shaped by national ideologies around which different social movements unfold. The contextual nature of nationalism still allows for identification of two different modes: western, rational, civic, territorial nationalism and eastern, organic, ethnic-genealogical nationalism (Smith 2000). Anthony Smith argues that ethnicity is a paramount premise in the formation of a nation, referring to the state-nation building model of Britain and France which were founded around a dominant ethnic group. Ethnicity defined as shared culture (common language, religion, customs), shared historical legacy, and a link to a specific territory (homeland) develops a strong sense of collective identity and solidarity. Stressing continuity between pre-modern ethnic groups and modern nations, Smith emphasises the core cohesive power of ethnic identity for the unfolding of nationalism: "[...] as an ideological movement for attaining and maintaining autonomy, unity and identity on behalf of a population [...]" (Smith 2000: 25).

In contrast to Smith's ethno-centrist origin of nationalism, Ernest Gellner (1983: 94) suggests that both modern nation-state model and nationalism had emerged due to political and cultural proximity of different ethnic groups, thus creating a new type of homogeneity. Nationalism based on territorial-political unity develops more 
sources for national cohesion and integrity while ethnic rooted nationalism could cause energetic separatist and isolationist trends.

Resurgence of nationalism in post-communist societies has also reshaped a wide range of nationalist ideologies and movements in the globalised world. In studies on genealogy of "East European nationalisms", social analysts stress the link between pre-communist and communist ideologies, the emergence of new emancipative ideas of subversion of previous forms of ideological colonisation, and state-nation building under the conditions of globalism (Altermatt 1998; Brubaker 2004; Puhle 2008). Rogers Brubaker says about the revival of new nationalism in post-communist countries: "[...] nationalizing nationalisms include appeals on behalf of one "main nation" or nationhood, defined in ethno-cultural sense and clearly detached from the community of citizens as a whole" (Brubaker 2004: 19).

Bulgarian studies on nationalism adopt the idea of the existence of a wide spectrum of nationalist views and sentiments. Nationalism has been comprehended in both positive, constructive and negative, destructive modes. According to Velev (2005: 6), a positive strand of modern nationalism is based on the idea of national unity, the defence of Bulgarian territorial integrity, and the construction of a modern national doctrine similar to the ideas of national independence and independent state building spread in times of Bulgaria's pre-liberation from the Turkish Ottoman Empire in the 19th century. An aggressive, destructive nationalism has been recognised as a mode of thinking that stirs up multiethnic tensions, conflicts, and xenophobic attitudes through language of hate and warlike rhetoric.

On the other hand, some sociologists (Kabakchieva 2008) observe a spread of strong nationalist attitudes among Bulgarians citing data from national representative studies, where Bulgarians avoid identifying with large communities, such as nation and state. Bulgarians demonstrate strong distrust in all public institutions; they are extremely disappointed by their political entities and leaders. Thus, it is argued that if nationalism had emerged in Bulgaria, it would hardly imply the identification with the state. Most Bulgarian people identify with their family settings and local communities that inspire the so-called "familial patriotism" instead of politically based nationalism.

Gal and Kligman (2001: 25) mention that it is remarkable that modern theorists of nationalism - Anderson, Smith, Gellner, Hobsbaum, Horowitz - ignore gender and reproduction. In contrast, some scholars in cultural studies put strong emphasis on the reproduction of the nation, which becomes a focal point in the nationalist discourses (Parker et al. 1992; Wilford/Miller 1998; Mayer 2000). In the second stream of theorising, biological reproduction has been discussed as a symbol of a nation's vitality and strength and a nation's liveliness considered as a social and genetic-biological entity. Decreased fertility of the nation has been viewed as stagnation of its vital potential, as a threat to gradual development, and as a symbol of the nation's death (Gal/Kligman 2001; Rivkin-Fish 2010).

Women are at the centre of nationalist thought as they represent the biological rejuvenation of the nation by reproducing cultural, lingual and gender identity and by becoming the allegorical emblem of the nation's continuity. Mothers are the symbol of a nation's viability, whereas women who do not reproduce indicate the 
nation's regress (Yuval-Davis 1997). Motherhood is viewed as the "primary form of female political agency" (Gal/Kligman 2001). Thus, nationalism claims control over women's reproductive capacities and morally condemns women who do not want to reproduce. In the socialist regimes, the states exercised strict control over women's bodies by making abortions illegal and restricting access to modern contraceptives. The socialist governments imposed an ideology that women were urged to have children in order to fulfil their patriotic duty; giving birth in the name of the communist party and state.

The family metaphor is central to nationalist thinking (Gal/Kligman 2001). The family is an exceptional entity because nation can be characterised as a big family. Family interests are superior to individual interests because the nation has survived and existed due to the reproduction of the family. Moreover, the image of the family is idealised as a traditional marital union where both parents raise children. All other types of family unions like monoparental family, homosexual family, or even childless family are ignored as they threaten the family's reproductive potential. The nationalist debate on reproduction goes hand in hand with normative debate about who are the "correct" producers and citizens of the nation.

Due to the effective enforcement mechanisms, modern nation-states exercise great power to regulate human reproduction, a process that Michel Foucault called "a biopolitics of the population" (Foucault 1990). Under the conditions of severe economic and political transformations and in face of population decline in most of East and Central European countries, politicians and leaders of the post-communist states debate how to stimulate women's fertility and how to cope with the negative consequences of low birth rates. These debates assure political legitimacy and state authority over these tackling demographic issues.

In the following sections we will analyse how the main characteristics of the nationalist discourse are constructed in the political agenda of VMRO and in the nationalist oriented talks in the internet forums. The centre of the nationalists' discourse is the "Roma problem", particularly the Roma minority's (fast) reproduction as a "threat" to the Bulgarian welfare and the people's wellbeing. ${ }^{3}$

\section{$4 \quad$ Nation and Roma ethnicity}

\section{1 "Gypsy issue at the heart of the demographic policy"}

The idea for ethnic homogeneity of the leading ethnic community takes a central role in the ethnonational vision of the nation. The higher birth-rate among the ethnic minorities combined with the lower fertility of the "dominant" ethnic group give

3 The "Roma problem" is also discussed in Hungary and Romania, where a large number of Hungarian and Romanian Roma live. The nationalists are actively involved in discussing minority policies in these countries by constantly producing negative stereotypes of Roma (Madroane 2012; Denes 2011) 
the nationalists rise to concern. They fear that the ethnic ratio in the country could change and turn the minority into majority. This worry is expressed by the claim of "expulsion and replacement of the Bulgarian people by the Gypsy ethnic group" (VMRO 2012). This concern permeates a large portion of the attitudes and opinions on the demographic crisis in Bulgaria. This view is most openly articulated by the VMRO leaders, e.g. "Bulgarian children on the verge of extinction", "Bulgarian population is dying out", "Today - a Muslim Netherlands, tomorrow a Gypsy Bulgaria", "SOS for Bulgarians", "Dobrudhza is depopulated and overrun by Gypsies", "One million less ethnic Bulgarians since the last census" (VMRO 2012). In VMRO's main document - "Bulgaria 2050 - demographic strategy project" the "Gypsy issue" is presented both from a quantitative perspective - the higher ethnic birth-rate - and from a qualitative aspect of the human capital - the ghetthoisation and marginalisation of this group:

"This is only the quantitative side of the problem. Unfortunately it has a qualitative, a social side as well, because there is a twofold model of reproduction in Bulgaria. On one hand, the larger population group has a low birth-rate (for ethnic Bulgarian it is below 7\% [sic]) which is rather insufficient for reproduction. On the other hand, the socially isolated and marginalised strata, which mainly consists of Gypsies, make $8 \%$ of the population, but give $20 \%$ of the live births and these shares are constantly increasing. This leads to further ghetthoisation of this group and does not help solving their problems in any way." (VMRO 2012)

Although the consequences of the "demographic crisis" are presented from a broader perspective - population ageing, increased retirement age, strains on welfare funds, prevalence of infertility among large number of Bulgarian families, problems with national security, migration pressure, and others - all these questions are deduced from the main problem identified by VMRO - the "disappearance of ethnic Bulgarians" and the impending "Gypsy threat" over the Bulgarian nation. On the VMRO's website the demographic crisis in Bulgaria is analysed and discussed in detail and a special subsection called the "Gypsy Issue" is dedicated to this topic. There are " $5+1$ urgent measures" proposed on the site, including combining child benefits with compulsory schooling and minimal living conditions, introducing different forms of community service in cases of insolvency and unpaid bills, penalties cutting social benefits and abolishing the equal treatment before the law of this ethnic group. These steps define the VMRO's proposed governmental policy for the integration of the Roma population, viewed as part of the efficient demographic policy.

The claim of anticipated ethnic dominance of Roma over ethnic Bulgarians is also constructed using statements of foreigners visiting Bulgaria. This view is exemplified in the words of a famous British journalist, who presents Bulgaria as a country where half of the population is "Gypsy":

"A scandalous film on BBC presented Bulgaria like a Gypsy country. The author is the British journalist Michael Palin famous as one of the actors of "Monty Python". His "picture" of our country steered a controversy at home and abroad. "Bulgaria is famous mostly with the fact that a lot of Gypsies live there. In this country they represent almost half of the population", said the author of the Eastern Delight film, reports Bulgarian National Radio" 
(Demographic Collapse in Bulgaria. In: http://forum.framar.bg, Date of publication 12.1.2012)

The "gypsyisation" of Bulgaria is viewed as a weakening of the cultural and historical power of the Bulgarian population and as a serious threat to the foundations of the state and the historic legacy of the country:

"The problem is not only in the depopulation. The Bulgarian statehood degrades as well. In more and more municipalities, Bulgarians are a minority. There, they are oppressed and discriminated. In the not too far future, the bigger part of the population of our homeland will not understand Bulgarian. [.....] Because the demise of Bulgarians means the disappearance of fifteen hundred years of Bulgarian civilisation and the end of the third Bulgarian state." (Kostadinov, Kostadin. In: Desant (Debark) Newspaper, Date of publication 26.2.2012)

Thus, in the VMRO's language on the "demographic crisis" we recognise a classic Malthus' discourse on population marked by the fear of irrationally high fertility of the lower strata, which poses a threat to the living conditions of the civilised middle-class of the Bulgarian society. The nationalists use the Malthusian argumentation of class-differentiated fertility in order to warn about the increase of allegedly inferior human capital, which would, in turn, result in the overall downgrading of the nation and the state. Thus, the VMRO's population discourse reproduces the main worries of the "apocalyptic demography": the shrinking of the superior, i.e. middleand upper-class population and the expanding of the inferior, "socially problematic" population. The VMRO's discourse on population is not new - this mode has shaped the political thinking about the population in Western Europe and the USA since the $19^{\text {th }}$ century until today (Etzemuller 2011)

\section{2 "The covert genocide turned into a financial one"}

The perceived "gypsyisation" of Bulgaria embodies another painful topic in the popular consciousness of Bulgarian citizens - the aspired distribution of common goods according to one's contribution instead of the current system, in which everyone is entitled to receive social benefits for unemployment, childcare, poverty, etc. The social discontent is instigated by media coverage of the supposed large spending on Roma integration and the miniscule, almost non-existent results. The latter is allegedly caused by the widespread corruption practices among the "Gypsy" activists, Roma organisation leaders and European project consultants dealing with Roma integration. "Expert" opinions on the topic by scholars from the Centre for Demographic Policy ${ }^{4}$ are often used and quoted by both VMRO leaders and the media:

4 The Centre for Demographic Policy is a recently founded NGO consisting of scholars, experts and activists with nationalist attitudes (including some VMRO leaders). Regularly, it publishes its own demographic reports, prognoses and evaluations that are widely spread by the mass media. The Centre claims to produce more "correct" and "true" statistical information on demographic issues than the official demographic information released by sources like the National Statistical Institute, the Demographic Department of the Institute for Population and Human Studies at Bulgarian Academy of Sciences, etc. 
"The Centre for Demographic Policy calculated that annually 3.1 billion leva are spent supporting the Gypsy community in Bulgaria. Those funds include social benefits, child allowances, maternal benefits, and others, legally distributed to the Roma population. This means that every Bulgarian - from the infant to the old man - pays 50 leva monthly for Roma support, calculates Prof. Petar Ivanov." (Roma build palaces using money set for their education. In: Monitor Newspaper, Date of publication 3.12.2011)

According to the $\mathrm{VMRO}$, during the years of the transition, the state has neglected the interests/needs of the working and tax-paying Bulgarian citizens and has instead favoured the Roma minority by granting them generous benefits including child allowances and thereby generating "a leeching sect pilfering from the Bulgarian majority" (Kostadinov, Kostadin. In: Desant (Debark) Newspaper, Date of publication 26.2.2012)

The VMRO leaders see the main reason for advantaging the group of Roma and the disenfranchising of the larger part of "Bulgarians" in the Roma voting power. During elections, Roma votes are often illegally purchased by political agents swaying election results in the Roma neighbourhoods. According to the VMRO position, maintaining the Roma marginalisation and poverty is seen as a prerequisite for continuing the illegal vote trade and as such benefits only politicians' interests. In the VMRO activists' views, the Roma are "political players" who can be easily manipulated and who are served by the state, which in turn burdens its tax paying citizens. The Roma represent "the main electoral body" (Dzhambaski $A$., Interview SKAT TV: 21.3.2012). “There are no reasons for a special treatment of Roma and to grant them more privileges.... the state discriminates Bulgarians, because Roma are more important voters", continued Dzhambaski in the same interview. According to the VMRO, the state refrains from responding to the problems with the Roma minority because:

"Gypsies are the only ethnic group in the country which reproduces, but this does not prevent the politicians to concoct new privileges for them in order to receive their votes. We see an excellent example for the saying "the sick carries the healthy one". The sick Bulgarian nation is forced to carry on its back the Gypsies who are multiplying like cockroaches." (Kostadinov, Kostadin. In: Desant (Debark) Newspaper, Date of publication 26.2.2012)

\section{3 "OUR money for THEIR (Gypsy) kids"}

The fear of turning Bulgaria into a "Gypsy" country and the outrage of the perceived preferential treating of the Roma minority is widespread in the media - newspapers, forums and blogs:

"I heard the following news on the radio: We are facing a demographic catastrophe, warned the professors from the Centre for Demographic Policy. According to their forecasts, which are based on the official census data, in 2050, there will be 3.5 million Gypsies in Bulgaria, 1.2 million Turks and barely 800 thousand Bulgarian people. Personally for me that is scary." (Demographic Collapse in Bulgaria. In: Framar forum, Date of publication 12.1.2012)

"WHOSE children do they [the politicians - T.K.\&E.D.] want to spend OUR money on? On THEIR (Gypsy) children! On the one hand, we are strength- 
ening the "occupants", on the other the traitors [...] (Spending funds - for police or for children? In: Sega (Today) Newspaper forum, Date of publication 12.12.2011)

"The Gypsy woman with five kids, receiving five child allowances, on top, I don't know what, social benefits, then for 2-3 of them she receives disability payments (because they are registered with chronic diseases) making 1500 leva per month. They live in the slums, the Gypsy father drives a new Mercedes. The Bulgarian mother with two children receives 70 leva child allowance and roughly 340 leva salary, and her husband drives his father's Fiesta from 20 years ago. So! Who's better off. Where does the welfare go?! I am not against helping those in desperate need, but being pikey has become a profession [...]" (Spending funds - for police or for children? In: Sega (Today) Newspaper forum, Date of publication 12.12.2011)

"In the end, those who work do not reproduce in more than 1:1 ratio, often at a lower rate, while those who do not work, reproduce intensively. They acquire greater influence over political players. Policies are prepared for them, programs are penned, financing and funds are planned. The welfare spending increases. The country becomes a bigger distributor, burdening the good citizens and serving the scroungers. Until the moment of crisis when everything crashes down. We arrived exactly at the turning point. But who cares?" (Spending funds - for police or for children? In: Sega (Today) Newspaper forum, Date of publication 12.12.2011)

These excerpts from internet forums demonstrate that worries about high fertility of Roma population are linked to people's increasing concerns of the economic difficulties experienced by an average Bulgarian family consisting of working parents with one or two children. Over the last 20 years of transition ordinary people paid a very high price for economic and social transformations. Many of them became more sensitive and demanding towards the post-communist governments which, by contrast to the previous communist governments, are expected to act in a most democratic way that guarantees social justice. As Susan Gal and Gail Kligman state: "[...] the issue of reproduction is one of the means by which the morality and desirability of political institutions is imagined [...]" (Gal/Kligman 2001: 28).

The national ideology namely exploits people's demographic fear and distrust in demographic and social politics of the post-communist state that endows the "Gypsy" minority with social benefits, and thus supposedly drains the meagre social welfare budget of the country. Keeping in mind the social structure of the contemporary Bulgarian society in which the middle class strata represents a tinny segment and almost 45 percent of the population live at risk of poverty and severe material deprivation (EU-SILC 2012), nationalists gamble with the individuals' perceptions of what is an un/fair social re-distribution. Outbursts of nationalism are illustrated in the hate speech used: The Roma minority is portrayed as "scroungers", "leeching sect", "cockroaches", and "pikey". The use of dichotomies ${ }^{5}$ is a common strategy to

5 Lundgren and Ljuslinder (2011: 165-183) describe how the dichotomization strategy is used for presentating population ageing in the media: old against young, economic active against supported, disaster against growth, etc. 
underscore the inferior nature of the Roma minority: our (Bulgarian money) against their (Roma kids), our (Bulgarian) money against their (Roma education), poorly paid workers (Bulgarians) against people living on social benefits (Roma mothers with many kids), honest citizens (Bulgarians) against corrupted voters (Roma), underprivileged (Bulgarians) against privileged (Roma), disappearance (of ethnic Bulgarians) against proliferation (of Roma). Therefore, the nationalists constantly produce borders, which divide the nation into two antagonistic parts - "we", the ethnic Bulgarians and the threatening "others", the Roma.

\section{The link between nationalism and pronatalism}

The nationalist vision of the future of a country goes hand in hand with pronatalism, understood as a state policy targeting an increased birth-rate (King 1998, 2001, 2002; Lee et al. 1991; Rivkin-Fish 2003; 2010). Usually, pronatalism flourishes during periods of fertility decline. In a context of increasing nationalism, pronatalism as a special state policy targets specific family types by taking into consideration their ethnic makeup.

In the VMRO's demographic vision, the state should support fertility of Bulgarians and restrict the Roma birth-rate. According to public opinion, however, the current policies lead to the opposite effect. To bring about the desired results, the VMRO offers a set of measures: differentiated access to family benefits and allowances, which are only granted to families with one or two children. The support for any further child, is only available to parents with secondary education. Implicitly, this measure assumes that only educated (Bulgarian) families with one or two children should be entitled to state support. Thus, higher fertility as a particular feature of the reproductive models of the non-Bulgarian ethnic groups would be tacitly discouraged.

These restrictive measures are widely supported by Bulgarians. The question, which was posed in an internet forum "Should the birth-rate in Bulgaria be limited to up to 3 children and to cancel child support for the next parenting (VMRO's proposal)?" was approved by 63.1 percent of 1088 voters. 30.3 percent disapprove, 4.8 percent could not decide and 1.7 percent had no opinion (Should the birth-rate in Bulgaria be limited up to 3 children. In: http://www.ndt1.com/polls, 6.4.2012).

Some experts also support the idea that child benefits for the fourth and any further parenting should be discontinued:

"It is necessary for the government to immediately propose and for the National assembly to pass a law, which regulates the following: give 35 leva, as currently done (if they can't do more) for the first child. For the second child, to support birth-rate among Bulgarians - give 50 leva and for the third - 70 leva, because it ensures positive natural growth, and for the forth - 35 leva again. For all following children - no child allowance. Mothers who've given birth before reaching the age of 18, should not only be denied any child allowance, the underage mothers as well as their parents should also be taxed." (Gavrilov: Taxes for mothers aged under 18. In: Duma newspaper, Date of publication 12.1.2012) 
The differentiated welfare support for childbirth which (implicitly) aims to penalise higher fertility of the Roma population questions the equality of the individual right to receive state support for every child in the family regardless of parity. Recently, the National Commission for Antidiscrimination, the preeminent state body on discrimination providing legal advice and monitoring, logged a complaint by a mother, who considers the differential state support for childbirth as unequal treatment based on "personal status":

"The woman explained why all Bulgarian citizens are discriminated by the state policy. According to her, the law aiming to curb the high birth-rate among the Roma families by decreasing the allowance for the third and higher order birth, affects all ethnic groups." (The birth bonuses are discriminatory. In: dir.bg, Date of publication 12.4.2012)

The Commission reviewed the complaint and acknowledged the discriminatory implication in the official policy of the state with regard to child benefits. As a result, it sent a letter to the Ministry of Labour and Social Policy in which the varying bonuses at birth are qualified as an indirect discrimination based on "personal status".

Thereupon, the Ministry published an official response stating that the current social policy stimulates families to have two children and that is why the bonus at birth for a second child is higher. The Ministry rejects "the claims for a connection between the bonus at birth and the goal of limiting fertility in a specific ethnic group" as "completely ungrounded" (The birth bonuses are discriminatory. In: dir. bg, Date of publication 12.4.2012)

One of the pillars of the demographic policy, according to the VMRO, is the state support for infertile families in Bulgaria. The special interest in this group is fostered by the observation that infertility is more common among ethnic Bulgarians and that supporting infertile couples to have children could partly solve the demographic problem of the country. Childless couples are viewed as a potential source of population increase. Moreover, the responsible parenting of these couples would guarantee proper care and upbringing of children.

"According to different sources, close to 250 thousand couples suffer from some sort of infertility. Infertility treatment methods used in the medical centres for assisted reproduction can help $60 \%$ of the couples, meaning that the Bulgarian nation has a potential for an increase with approximately 150 thousand highly desired babies." (VMRO 2012)

Bulgarian society unanimously approves the state financial support for infertile couples. Nobody questions the redistribution of tax money to these families, although the committing of funds at times of economic hardships and low income rates is a legitimate concern. More importantly, by this support, the state legitimises its power to control the nation's reproduction. The demographic argument ${ }^{6}$ is actively used by the initiators of this support - NGOs defending the interests of

6 Experts reject the thesis that reproduction by assisted technologies could recover low levels of fertility. For more details see e.g.: Kotzeva/Dimitrova 2009. 
people with fertility problems as well as by medical specialists involved in infertility treatment.

\section{1 "The most dangerous strike is that of the mothers - they simply refuse to give birth"}

In online forums, young people discuss the hardships of raising children and the deficit of family-friendly policies by the state, labelling their position as "strike". But who is the target of young mothers' "strike"? Women share the view that they have to go on strike, i.e. to refuse having more than one child, because the employer (the state - in their view) does not fulfil its responsibilities. One of the widely discussed topics in the forums is that the Bulgarian state owes money and services to the mothers - family support and income need to be increased, because they are insufficient to support childbearing; young people need to be provided e.g. with work. In this way, the reproduction changes from a personal or a family decision to a state decision. This etatist type of attitudes are widely exploited by the nationalist opinion leaders. In the nationalist vision, it is the state which carries full responsibility for the country's "demographic crisis". The refusal to have children expresses the breached contract between women, family and the state. This is why, in the popular belief, as well as in the nationalist "claims", the "demographic crisis" symbolises the disintegrating statehood.

In the nationalist discourse, the nation represents an extended family, and the family reproduces the nation. This places an exclusive responsibility on the family to preserve the nation. Thus, nationalists criticise not only the state's ignorance of the demographic issue but also families/women who escape their responsibility for the future reproduction of the nation. ${ }^{7}$ In the nationalist view, the erosion of the traditional family values, the decline of moral family norms, and the dilution of traditional gender roles in the modern society are emphasised as the main reasons for a reproductive mission of the family which is perceived faulty:

"We conducted our research in three large university cities. The larger group of the respondents replied that they don't want to get married. Women argue that men have become more feminine, you can't rely on them to support a family. Men, on the other hand, find women to money driven and so on. These responses do not depend on the financial status of the respondents - this is the opinion of both wealthy and poor. The truth is that even at the beginning of the 1990s, we scrapped education from school. The family teaches moral values, while the school-social ones. A generation grew up without those values, now children are considered as a burden, not as a value. And we are wondering why Bulgarians are degrading, why the nation is becoming dumber. That is why, because of the missing value system." (Kostadinov, Kostadin: The third national catastrophe. Date of publication 15.5.2012)

7 Similarly, moral discourse on blaming women for rejecting motherhood and pursuing selfish priorities (professional career, etc.) has been enhanced by the Catholic Church and the nationalist governments in the postsocialist Poland (Mishtal 2012: 153-169). 
In some internet blogs and forums, the demographic crisis is explained not so much by severe material restrictions experienced by the majority of Bulgarians, but by the lack of moral pillars, translated into "moral degradation" and "spiritual squalor" of generations born after 1989. In the forum discussions, the "demographic crisis" is part of the larger degradation of the state together with corruption, mafia connections of the state, crime, economic crisis, high prices of utilities, low salaries, and similar calamities (Gypses Bullying Bulgarians. In: forum hooligans.bg, Date of publication 6.3.2012). The demographic crisis is viewed as a result and at the same time, as another manifestation of the moral debasement of Bulgarian society, in which the profane and the sinfulness are expressed in the rejection of traditional values like marriage, children and collective responsibility.

\section{$6 \quad$ Concluding remarks}

The aim of this paper was to study how Bulgaria's steep population decline during the post-communist transitional years has been interpreted in the nationalist ideology and nationalist public consciousness. An analytical grid developed on the basis of theories of nationalism, particularly the idea of its resurgence in post 1989 Eastern Europe (Altermatt 1998; Brubaker 2004), filtered through the concept of "reproduction as politics" (Gal/Kligman 2001), has been used to analyse main topics in the nationalist discourse on the population problem and declining birth-rates in contemporary Bulgaria.

In trying to shed light on the complicated relationship between nationalism and reproduction in the Bulgarian post-communist context, we start from the idea that reproduction is a key dimension of the relationship between the state and the citizens in modern times. It becomes an object of a legitimised control exercised by the state by various policies and institutional mechanisms aiming to influence individuals' reproductive decisions.

Nationalism as one of the most influential ideologies of the modern and postmodern societies constructs the essence of the reproduction policies: who can reproduce the nation, how many children are needed for the nation-state to guarantee its continuity, who is responsible for the reproduction, what is moral in terms of distribution of social welfare - these are questions which define the parameters of the political actions undertaken in the realm of family and reproduction. The analysis of public discourse on the "population problem" and the "demographic crisis" manifests the main arguments of the ideology of (ethno)nationalism for the creation of the nation as "imagined community" (Anderson 1991). Nationalism seeks and offers "solutions" for the demographic crisis by tacitly differentiating the social policy based on ethnicity, by rejecting immigration of people with "non-Bulgarian" origin, and by escalating pronatalist rhetoric and thus being nostalgic about lost traditional family values. Identifying themselves as "national responsible citizens", VMRO's activists plead for the revival of the prestige of the "normal" family, but at the same time avoid the discussion on how to implement family-friendly policies. 
Nationalist ideology is grounded on the people's sentiments and emotional attachment to their homeland on one hand, but it is challenged by the ongoing processes of Bulgaria's integration into the European Union and the globalised world, on the other. In this context, anti-Roma campaign of the nationalist ideology (anti-Tsiganism) of the nationalist ideology instead of constructive policy proposals leads to the reinforcement of negative stereotypes towards minorities and to an emerging of multiethnic tension. The nationalist divide of the nation into "worthy" and "non-worthy" segments of population violates the principle of universality of human rights and creates superiority of one ethnic group in the realm of reproduction. On the other hand, nationalists do not back practice of positive discrimination towards the Roma community on the ground of its disadvantaged position because this policy of favouring individuals would antagonise the rest of the population. All these contradictions of the nationalist discourse indicate its inability to offer constructive solutions to the demographic problem existing in contemporary Bulgaria.

\section{References}

Altermatt, Urs 1998: Etnonatzionalizmat v Evropa. Sofia: Oksiart [A/termatt, Urs 1996: Das Fanal von Sarajevo. Ethnonationalismus in Europa. Zürich: Verlag Neue Zürcher Zeitung].

Anderson, Benedict 1991: Imagined communities: reflections on the origin and spread of nationalism (Revised and extended. ed.). London: Verso.

Brubaker, Rogers 2004: Natzionalizmat v novi ramki. Sofia: Kritika I humanism [First published as: Brubaker, Rogers 1996: Nationalism Reframed: Nationhood and the National Question in the New Europe, Los Angeles: University of California Press].

Coleman, David; Rowthorn, Robert 2011: Who is afraid of population decline? A critical examination of its consequences. In: Population and Development Review 37 (Supplement): 217-248 [doi: 10.1111/j.1728-4457.2011.00385.x]:

Demographic processes 2013. Sofia: NSI. [http://www.nsi.bg/EPDOCS/Population2012. pdf, 15.5.2013]:

Demographic Collapse in Bulgaria 12.1.2012: [http://forum.framar.bg, 15.7.2012].

Denes, Gustavo Voeroes 2011: Ossified Discrimination: Demystifying Policy and Conventional Frames to the Hungarian Romani by 'Myth' Deconstruction. MA thesis. Institute of Social Studies, The Hague, the Netherlands.

Dimitrova, Elitsa 2012: Stratifying Reproduction: Social Inequalities and Second Birth in Bulgaria After 1990. In: International Journal of Sociology 42,3: $34-53$ [doi 10.2753/ IJS0020-7659420301].

Dimitrova, Elitsa 2011: Promeni w ravdaemostta w Bulgaria: powedencheski i cennostni izmerenia (Fertility Changes in Bulgaria: Behavioral and Value Aspects). Sofia: "Prof. Marin Drinov" Press. (In Bulgarian).

Dzhambaski A.: Interview SKAT TV 21.3.2012 [http://www.vmro.bg/index.php?option $=$ com_content\&view =article\&id=4017:2012-03-21-10-4318\&catid=14:2012-01-20-10-17-13\&ltemid $=53,15.7 .2012]$. 
EC (European Commission) 2011: European Demography Report 2010. Commission Staff Working Document [www.ec.europa.eu/social/BlobServlet?docld=6824\&langld =en, 15.7.2012].

Etzemuller, Thomas 2011: The Population Discourse: A Transnational Matrix. The Case of Germany and Sweden. In: Historical Social Research 36,2: 101-119.

EU-SILC 2012: European Union Statistics on Income and Living Conditions [http://epp. eurostat.ec.europa.eu/portal/page/portal/microdata/eu_silc 20.10.2013].

Foucault, Miche/ 1990: The History of Sexuality. Vol.1 New York: Pantheon Books.

Gal, Susan; Kligman, Gail 2001: The Politics of Gender after Socialism. A ComparativeHistorical Essay. New York: Princeton University Press.

Gavrilov, Ivan 12.1.2012: Taxes for mothers aged under 18. Duma Newspaper [http:// duma.bg/duma/node/25267, 15.7.2012].

Gee, Ellen; Gutman, Gloria (Eds.) 2000: The Overselling of Population Aging: Apocalyptic Demography, Intergenerational Challenges and Social Policy. Oxford: Oxford University Press.

Gee, Ellen 2002: Misconceptions and Misapprehensions About Population Ageing. In: International Journal of Epidemiology 31,4: 750-753 [doi: 10.1093/ije/31.4.750].

Gellner, Ernest 1983: Nations and Nationalism. Oxford: Blackwell Press.

Greenhalgh, Susan 1990: Toward a Political Economy of Fertility. In: Population and Development Review 16,1: 85-106 [doi: 10.2307/1972530].

Gypses Bullying Bulgarians 6.3.2012: [http://hooligans.bg/forum/viewtopic. php?pid=126105, 15.7.2012].

Hamilton, Roberta 1995: Pronatalism, feminism and nationalism. In: Gigras, FrancoisPierre (Ed.): Gender Politics in Contemporary Canada. Toronto: Oxford Univ. Press.

Isola, Anna-Maria 2008: Fertility concern in Finland and Russia: Economic thinking and ideal family size in the rhetoric of population policies. In: Finnish Yearbook of Population Research 43: 63-84.

Kabakchieva, Petya 2008: Not to provoke 'bad fortune'. In: Politics 10 (Open Society Institute) [http://politiki.bg/?cy=123\&lang $=1 \& a 0 i=223208 \& a 0 m=$ readlnternal\&a0p_ $\mathrm{id}=411,15.7 .2012]$.

Keller, Reiner 2005: Analysing Discourse. An Approach From the Sociology of Knowledge. In: Forum: Qualitative Social Research 6,3 [http://www.qualitative-research. net/index.php/fqs/article/view/19, 15.8.2012].

King, Leslie 1998: "France needs children": pronatalism, nationalism and women's equity. In: The Sociological Quarterly 39,1: 32-52 [doi: 10.1111/j.1533-8525.1998.tb02348.x].

King, Leslie 2001: From pronatalism to social welfare? Extending family allowances to minority populations in France and Israel. In: European Journal of Population 17,4: 305-322 [doi: 10.1002/oa.781A].

King, Leslie 2002: Demographic trends, pronatalism and nationalist ideologies in the late 20th century. In: Ethnic and Racial Studies 25,3: 367-389 [doi: 10.1080/01419870020036701d].

Kohler, Hans-Peter; Billari, Francesco; Ortega, Jose Antonio 2002: The Emergence of Lowest-Low Fertility in Europe During the 1990s. In: Population and Development Review 28,4: 641-680 [doi: 10.1111/j.1728-4457.2002.00641].

Kostadinov, Kostadin 2012: Nation - in front of demographic collapse. 26.2.2012 In: Desant (Debark) Newspaper [http://www.desant.net/show-news/23978/, 15.7.2012]. 
Kostadinov, Kostadin 2012: The third national catastrophe, 15.5.2012 [http://www.vmro. bg/index.php?option $=$ com_content\&view $=$ article\&id $=1467 \% 3 A 2010-11-30-09-33-$ 13\&catid=9\%3Aactualfltemid $=1,15.7 .2012$ ].

Kotzeva, Tatyana 2011: Public Discourses, Social Policies and Gender Arrangements in the Post-Socialist Context of Low Fertility in Bulgaria. In: Kahlert, Heike; Schäfer, Sabine (Eds.): Engendering Transformation. Post-Socialist Experiences on Work, Culture and Politics. Gender Special Issue No. 1. Opladen/Berlin: Farmington Hills/Mi: Barbara Budrich Publishers: 107-124.

Kotzeva, Tatyana; Dimitrova, Elitsa 2009: Involuntary Childlessness in Bulgaria - a SocioDemographic Issue of Significant Concern. In: Naidenova, Penka; Mihova, Genoveva (Eds:): Fertility in Bulgaria and State Policy. Sofia: CPS: 113-129 (In Bulgarian).

Koytcheva, Elena; Philipov, Dimiter 2008: Bulgaria: Ethnic differentials in rapidly declining fertility. In: Demographic Research 19,13: 361-402 [doi: 10.4054/DemRes.2008.19.13].

Krastev, Ivan 2011: Generation E. In Kapital, 15. 9. 2011 [http://www.capital.bg/light/ lightest_2011/2011/09/15/1156885_pokolenieto_e/, 15.7.2012].

Krause, Elizabeth 2001: "Empty Cradles" and the Quiet Revolution: Demographic Discourse and Cultural Struggles of Gender, Race and Class in Italy. In: Cultural Anthropology 16,4: 576-611 [doi: 10.1525/can.2001.16.4.576].

Lee, Sharon; Alvarez, Gabriel; Palen, John 1991: Fertility decline and pronatalist policy in Singapore. In: International Family Planning Perspectives 17,2: 65-73 [doi: 10.1086/225399].

Lundgren, Anna S.; Ljuslinder, Karin 2011: Problematic Demography: Representations of Population Ageing in the Swedish Daily Press. In: Journal of Population Ageing 4,3: 165-183 [http://www.ep.liu.se/ej/ijal/2011/v6/i2/ijal11v6i2-complete_issue. pdf\#page=39, 15.10.2012].

Madroane, Irina Diana 2012: Roma, Romanian, European: A Media Framed Battle over Identity. In: Critical Approaches to Discourse Analysis across Disciplines. In: Critical Approaches to Discourse Analysis Across Disciplines (CADAAD) 5,2: 102-119.

Maroney, Heather 1992: "Who has the baby?" Nationalism, pronatalism and the construction of a 'demographic crisis' in Quebec 1960-1988. In: Studies in Political Economy 39: 7-36.

Mayer, Tamar (Ed.) 2000: Gender Ironies of Nationalism. Sexing the Nation. London/ New York: Routledge.

Mayring, Philipp 2000: Qualitative Content Analysis. In Forum: Qualitative Social Research 1,2 [http://www.qualitative-research.net/index.php/fqs/ article/view/1089/2386, 15.8.2012].

Mirchev, Michail 2010: Sotsialna Dinamika I Tsivilizatsionno razslojavane (Social Dynamics and Civilization Divide). Sofia: ASSA-M.

Mishtal, Joanna 2012: Irrational non-reproduction? The 'Dying Nation' and the Postsocialist Logics of Declining Motherhood in Poland. In: Anthropology \& Medicine 19,2: 153-170 [doi: 10.1080/13648470.2012.675048].

National Health Strategy for People Belonging to Ethnic Minorities 2005-2012: [http:// www.ncedi.government.bg/zdravna\%20strategia_prieta.htm, 15.7.2012].

Parker, Andrew; Russo, Mary; Sommer, Doris; Yaeger, Patricia (Eds.) 1992: Nationalisms and Sexualities. New York/London: Routledge.

Population Census Report 2011: Sofia: NSI [http://www.nsi.bg/EPDOCS/Census2011final.pdf, 15.7.2012]. 
Puhle, Hans-Jürgen 2008: New nationalisms in Eastern Europe - a sixth wave? In: Egbert, Jahn (Ed.): Nationalism in Late and Post-Communist Europe. Volume 1 - The Failed Nationalism of the Multinational and Partial National States. Baden-Baden : Nomos: 153-171.

Rivkin-Fish, Michele 2003: Anthropology, demography and the search for a critical analysis of fertility: insights from Russia. In: American Anthropologist, New Series 105,2: 289-301 [doi: 10.1525/aa.2003.105.2.289].

Rivkin-Fish, Michele 2010: Pronatalism, gender politics and the renewal of family support in Russia: towards a feminist anthropology of "maternity capital". In: Slavic Review 69,3: 701-724 [doi http: //dx.doi.org/10.1177/ 01925139701800600].

Romas build palaces using money set for their education 3.12.2011: In: Monitor Newspaper [www.monitor.bg, 15.7.2012].

Should the birthrate in Bulgaria be limited up to 3 children 2012: 6.4.2012 [http://www. ndt1.com/polls/index. php?qid=2011-02-02\&aid=-15.7.2012].

Spending funds - for police or for children? 2011: Sega (Today) Newspaper forum, 12.12.2011 [http://www.segabg.com/replies.php?id=196699\&v=3939167, 15.7.2012].

Smith, Anthony 2000: Natzionalnata identichnost. Sofia: Kralitsa Mab [Firtst published as: Smith, Anthony 1991: National identity. Reno: University of Nevada Press].

The birth bonuses are discriminatory 12.4.2012 [www.dir.bg, 15.7.2012].

Velev, Grigor 2005: (Nacionalizym) Nationalism. Sofia: Znanie Press (in Bulgarian).

Vincent, John 1996: Who is Afraid of an Ageing Population? Nationalism, the Free Market, and the Construction of Old Age as an Issue. In: Critical Social Policy 16,3: 3-26 [doi: 10.1177/026101839601604701].

VMRO 2012: Bulgaria 2050 - demographic strategy project [http://www.vmro.bg/index. php?option $=$ com content\&view $=$ article\&id $=321:-2050$ - \& catid $=17: 2012-01-20-10-17$ 34\&ltemid=49, 15.7.2012].

Wilford, Rick; Miller, Robert L. (Eds.) 1998: Women, Ethnicity and Nationalism: The Politics of Transition. New York/London: Routledge.

Yuval-Davis, Nira 1997: Gender and Nation. London: Sage Publications.

Prof. Dr. Tatyana Kotzeva $(\bowtie)$. Institute for Population and Human Studies, Bulgarian Academy of Sciences, Sofia; Burgas Free University, Burgas. Bulgaria.

E-Mail: tanyakotzeva@gmail.com

URL: http://www.bfu.bg/bg/tsentar-po-humanitarni-nauki/akademichen-sastav/ personalna-stranitsa-na-prepodavatel?teacher $=337$

Assoc. Prof. Dr. Elitsa Dimitrova. Institute for Population and Human Studies, Bulgarian Academy of Sciences. Sofia, Bulgaria.

E-Mail: elitsa_kdimitrova@yahoo.com

URL: http://www.iphs.eu/n/index.php/departament-demografiya/vazproizvodstveniprotzesi-i-strukturi-na-naselenieto 


\section{Comparative Population Studies}

WWW.comparativepopulationstudies.de

ISSN: 1869-8980 (Print) - 1869-8999 (Internet)

Published by / Herausgegeben von

Prof. Dr. Norbert F. Schneider

Federal Institute for Population Research

D-65180 Wiesbaden / Germany

Managing Editor /

Verantwortlicher Redakteur

Frank Swiaczny

Assistant Managing Editor /

Stellvertretende Redakteurin

Katrin Schiefer

Language \& Copy Editor (English) /

Lektorat \& Übersetzungen (englisch)

Amelie Franke

Copy Editor (German) /

Lektorat (deutsch)

Dr. Evelyn Grünheid

\section{Layout / Satz}

Beatriz Feiler-Fuchs

E-mail:cpos@bib.bund.de

\author{
Scientific Advisory Board / \\ Wissenschaftlicher Beirat \\ Paul Gans (Mannheim) \\ Johannes Huinink (Bremen) \\ Michaela Kreyenfeld (Rostock) \\ Marc Luy (Wien) \\ Clara H. Mulder (Groningen) \\ Notburga Ott (Bochum) \\ Peter Preisendörfer (Mainz) \\ Zsolt Spéder (Budapest)
}

\section{Board of Reviewers / Gutachterbeirat} Martin Abraham (Erlangen)

Laura Bernardi (Lausanne)

Hansjörg Bucher (Bonn)

Claudia Diehl (Konstanz)

Andreas Diekmann (Zürich)

Gabriele Doblhammer-Reiter (Rostock)

E.-Jürgen Flöthmann (Bielefeld)

Alexia Fürnkranz-Prskawetz (Wien)

Beat Fux (Salzburg)

Joshua Goldstein (Berkeley)

Karsten Hank (Köln)

Sonja Haug (Regensburg)

Aart C. Liefbroer (Den Haag)

Kurt Lüscher (Konstanz)

Dimiter Philipov (Wien)

Tomáš Sobotka (Wien)

Heike Trappe (Rostock) 